\title{
Ownership Structure and Financial Performance of Islamic Banks in Pakistan, Does Bank Ownership Structure Matter?
}

\author{
Shama Noreen \\ Lecturer, Department of Management and Administrative Sciences, University of Narowal, Narowal
}

\author{
Ahsan Ameen* \\ Department of Management and Administrative Sciences, University of Narowal, Narowal \\ Sidra Tariq Ayesha Bashir \\ Department of Management and Administrative Sciences, University of Narowal, Narowal
}

\begin{abstract}
The basic purpose of this study is to investigate the determinants of ownership structure and their impact on performance of Islamic banking in Pakistan. Multiple techniques such as descriptive, regression and correlation analysis are used to check the ownership structure and financial performance of Islamic banking in Pakistan. We used secondary Data collected from published annual reports of Islamic banks and apply E-views software to check determinants of ownership structure and their impact on profitability of Islamic banking for this purpose $\mathrm{C} 1, \mathrm{C} 3$ and $\mathrm{C} 5$ variables use for ownership concentration, family, individual, institutional and government use for ownership mix as an independent variable and used bank characteristics and micro economic factor as a control variables and their impact on financial performance check through Return on assets (ROA) return on equity (ROE). The finding of this study shows that (C1) largest shareholder, government (GOV) and foreign shareholder negatively related to return on assets (ROA) whereas (C3) the percentage of first three largest shareholders and (C5) the percentage of first five shareholders insignificantly and negatively related to the return on equity while in ownership mix (INST) institutional shareholders and (FAM) family shareholders negatively influence the return on equity (ROE) on the other hand (GOV) state and (FORG) foreign shareholder positively influence the return on equity. In short results of this research conclude that ownership structure effect the financial performance of Islamic banks in Pakistan. This research helpful for financial advisor and investors for investment purpose. This study add value to the literature by exploring ownership structure and their impact on performance of Islamic banking and also provide information to investor about investment purpose and also increase the efficiency and effectiveness of Islamic banks.
\end{abstract}

Keywords: Ownership structure, Financial performance, Islamic banking, Pakistan

DOI: $10.7176 /$ RJFA/10-5-04

Publication date:March $31^{\text {st }} 2019$

\section{Introduction}

The banks play an important role in developing economies as financial institutions and also considered extraordinary essential for economies functions. The economic growth also impacts on financial institution efficiency. The profitability of banking sector contributes in economic growth and makes economies to tolerate depressing and external financial crisis and also contributes in stability of financial system (Athanasoglou et al. 2005). For that motivation, it is important to understanding about performance and ownership structure of banking sector.

Islamic banking is a system which approach into continuation on the basis of Islamic laws and beliefs. Conventional banking works as financial institution but on the other hand Islamic banking is acknowledged as trade oriented business. Conventional banking earns income in the form of fix interest while Islamic banking earns in form of profit. The main purpose of emerging Islamic banking is to eliminate the interest (Riba) from all business deals. According to Islamic laws (Shariah) all financial organizations are free from the interest (Riba). Riba (interest) has also forbidden in the Holy Quran. That's why it is banned in the surfacing Islamic banking. Sharing risk and reward are two fundamental things in Islamic banking structure.

The major purpose to systemize the Islamic banking is the Muslim societies to organize their evolution of business and also all changes must be liberated from interest (Riba) according to Islamic laws. The investment in which division of profit (reward) and loss (risk) according to Islamic laws. Islamic banking industry is prominent due to unbiased distribution of wealth and free from interest (Riba).

Ownership structure plays vital role in determining the financial performance of institution and also important for allusion of corporate governance. Ownership structure is described in two ways in shape of ownership mix and concentration. In ownership concentration determiners the power of shareholders in which owner organized and manipulates the management of the firms to maintain their interest. However, when ownership of a company is concentrated, large shareholders plays an important role to monitor the management 
(Zhuang, 1999). Ownership concentration is generally used in most countries. According to Thomsen and Pedersen (2000) ownership concentration is differ from different type of shareholder. In ownership mix included ownership of different shareholders like government family, individual, institution and foreign companies etc Studies that have tried to explain the performances of Islamic banks are limited as Compared to the rich literature on this concern for conventional banks (Zouari \& Taktak, 2012) now Islamic banks exist all over the world while they were initially developed to accomplish the need of Muslim.Combining ownership allows concentrated shareholder to exchange their profit for private rents (Fama and Jensen 1938).Islamic bank can stay alive all over the world even within conventional banking support.

"Ownership structure and financial performance of Islamic banks" for achieving good performance banks use different tools techniques and strategies, one of the best strategy is ownership structure so that we can check the relationship between ownership structure and performance of banks. Ownership structures have the key importance in corporate governance because they affect the efficiency of management and performance of business. Basically ownership structure shows the voting rights equity and ownership of shareholders. The main purpose of this research is to investigate the relationship between ownership structure and its impact on Islamic bank's financial performance, either family institutional government matter for bank performance or not because conventional bank differ from Islamic bank. Islamic banks are available in Pakistan.

The founder of Pakistan Quaid-e-Azam was more interested in Islamic banking in our state. The main purpose of state bank was to eliminate interest organism from Pakistan. The Islamic banking was not more famous, but it was most familiar in worldwide at the start of 20 s century. Islamic banking is increasing with the ratio of $11.15 \%$ and 500 billion US dollar approximately accounts value. According to the economical and different researcher point of view interest free economy is important for any country. Islamic banking is prominent at national level in Pakistan and the major work started in 1980s. The policies of banks change by the state bank and on the other hand in Pakistan the ruling body made for execution of Islamic banking (Khakan and Rabia, 2016).

Banks play an important role in the different segments of economy of the country. The country government banks were privatized due to poor performance in 1992. The state bank was functioning as Islamic bank in 2000 and in Pakistan Meezan bank was registered as first Islamic bank in 2002. In present century the growth of Islamic banking sector is threat for conventional banks in different countries like as Pakistan, Malaysia and Bahrain. The fundamental of Riba (interest) and loss sharing policies create differential between the Islamic and conventional banking.

Banking sector of Pakistan is a well structured especially Islamic banking sector has been performing better for last few years. The banking sector of Pakistan contains different categories of banks i.e. Islamic banks, local banks, foreign banks, public and private banks. Ownership structure of each bank is dissimilar and it affects its financial performance. In this study researchers explained ownership structure by two types i.e. ownership concentration $(\mathrm{C} 1$ :The percentage of shares held by the largest shareholders, $\mathrm{C} 3$ :The percentage of the first three largest shareholders, C5:The percentage of the first five largest shareholders) and ownership mix (foreign, government, institutional and family ownership) is study to discover the relationship between ownership structure and financial performance of Islamic banking sector of Pakistan.

There is an extensive amount of literature on the subject of the effects of ownership structure on corporate performance from developed countries like UK, US and European countries. On the other hand, there is a gap in methodical particulars for developing countries, especially for Pakistan. Before this research the study on Islamic banking is not prepared in Pakistan. Islamic banking sector plays a central part in building up the economy of Pakistan and it needs to be deliberate in relation with its shareholding patterns and its effect on its financial performance.

\subsection{Research questions}

1: Does ownership concentration affect the financial performance of Islamic banks?

2: Does ownership mix affect the financial performance of Islamic banks?

\section{Literature Review}

This section provides a comprehensive review of the related literature on different aspects of ownership structure and financial performance. It comprises the concept of ownership concentration, ownership mix, financial performance and its comparison.

\subsection{Ownership Concentration}

Shareholders are owners of firms and management board works on behalf of owners of business to increase their profit. Several studies depict that the ownership concentration has multifarious relationship with the performance of firms (Demsetz, 1983; Demsetz \& Lehn, 1985; Shleifer \& Vishny, 1986). Due to that reason these findings are contradictory and indefinite, it becomes remarkable to research the charter of this relation for Islamic 
banking sector, which shows differences in language of economic, institutional and political conditions.

Lepore et.al (2017) founded in their study the higher ownership concentration have positive impact on firms performance with a competent judicial system of companies. A study conducted by Abdallah \& Ismail, (2017) in which they founded that the corporate governance has positive relationship with firms' performance and it is an escalating role of dispersed ownership. Also describes that value adding of excellent corporate governance is not compulsory maintained with high ownership concentration. Bian \& Deng, (2017) conducted a study examined the Chinese banks for the time period 2007 to 2014 and found that the higher ownership concentration enhance the financial performance ( return on asset and return on equity) of banks and decrease the percentage of non-performing loans. A study conducted by Phung \& Mishra, (2016) examined the impact of ownership structure on firms performance over the time period 2007 to 2012 and found that the ownership structure has non-linear relationship with firms performance. They also describe that the firms performance improves that have foreign ownership.

The study conducted by Pervan et al. (2012) for investigate the relationship among ownership structure and financial performance (return on asset) for listed companies in Croatia. They found that the companies have higher financial performance (return on asset) that listed with single ownership than those firms that have concentrated ownership. Same as, Alam \& Deb (2010) and Brammer \& Pavelin (2006) find the negative relationship among the ownership concentration and level of disclosures between companies listed in Bangladeshi and British respectively. Banghoj \& Plenborg, (2008) found in their study the results of more ownership concentration are that it may present less intentional performance because shareholders obtain information through internal communication channels. Lakhal, (2007) examined the sample of 207 listed of French companies for the time period 1998 to 2001 and find that ownership concentration has negative impact on intentional earnings. The study conducted by Iannotta et al. (2007) to examined the relationship among the ownership structure, risk taking and financial performance of 181 banks of Europe during the time period 1999 to 2007. They found that the ownership concentration has insignificantly impact on profitability of banks while the more ownership concentration is linked with higher loan quality, lower insolvency and asset risk, so increased the performance of banks. Welch, (2003) investigated the relationship of ownership structure and firms performance of listed firms in Australia by adopting the model of Demsetz \& Villalonga, (2001). He found that the firms' performance significantly affected by the top management ownership while he also describe that when the performance is measured by Tobin's-Q model the result shows insignificant. The firm's performance and ownership structure have insignificant relationship founded by Demsetz \& Villalonga, (2001).

Lehmann \& Weigand, (2000) conducted a study to examine the impact of corporate governance on firm's performance during the time period 1991 to 1996 and 361 German firms selected as sample of study. They found that the ownership concentration unenthusiastically affects profitability of companies while they also observe that elevated ownership concentration just improves the financial performance of those firms listed with large shareholders. There are different results provided by several studies on the relationship of ownership concentration with level of disclosures. Furthermore, some researchers find that the correlation of ownership concentration have negative relation with level of disclosure (Cooke, 1989; Chau \& Gray, 2002; Haniffa \& Cooke, 2002; Barako et al., 2006; Huafang \& Jianguo, 2007; Patelli \& Prencipe, 2007; Tsamenyi, et al., 2007). For the perspective of corporate governance and financial performance, the ownership concentration plays an important role (Eng \& Mak, 2003; Ntim \& Soobaroyen, 2013).

Managers will have minor incentives for better disclosures of performance, firms with high level of ownership concentration. Hossain et al. (1994) investigate that management of ownership structure and the intensity of voluntary disclosure has negative relationship in Malaysian companies. A study conducted by Leech \& Leahy, (1991) in which found that ownership concentration and firms profitability have negative relationship for large British firms implying from the above ground ownership concentration has harmful possessions for firms profitability. In 1999, La Porta et al. conducted a study that examine the dilemma of ultimate control, i.e. they investigate the sequence of ownership and whose shareholder has the large part of voting power. The findings depicts that the ownership and management can be estranged to the benefits of the large shareholders.

\subsection{Ownership mix}

In literature, there is consent relating to the ownership mix and defined in a way that ownership mix is dividing into share held by family, single person, foundation, state institutional, foreign investor and general public (Taktak, OWNERSHIP STRUCTURE AND FINANCIAL, 2012; THOMSEN, 2000; Sarra Ben Slama Zouari, 2014; Parveen, 2014).Also study investigated that corporate governance practices implement according to ownership structure in Malaysia and find good performance especially privately and domestically owned bank.(Peong Kwee Kim, 2012).

Family ownership; Recent research identification is that primarily families hang on high ownership all over the world. Researcher examined that sometime shareholder is state but mostly shareholders are owner.(RAFAEL LA PORTA, Corporate Ownership Around the World, 1999). Family ownership is beneficial and positively affects 
the financial performance of Islamic bank (Sarra Ben Slama Zouari, 2014; Taktak, OWNERSHIP STRUCTURE AND FINANCIAL, 2012; REEB, 2003)

State ownership; Researcher examined that State ownership is valuable for financial performance of Islamic bank. State ownership signifies a large stake in developing countries and most of the world's country where the state control the bank. (Sarra Ben Slama Zouari, 2014; RAFAEL LA PORTA, Government Ownership of Banks, 2002; James S. Anga, 2006; Tian*, 2007). Researcher investigated, Two theories are discussed "political" and "development" theories and find consistent result with political view of Govt. ownership which reduce efficiency and in later theories Govt. ownership of bank is allied with slower financial and economic development as well as in poor countries.(RAFAEL LA PORTA, Government Ownership of Banks, 2002).

Institutional ownership; Researcher found that there is positive relationship between institutional ownership and firm performance (Smith 1996).Study examined that banks with foreign and institutional shareholders are not performing than those who are family and government owned Zouari, S.(2014).

Foreign ownership; Researcher investigate that foreign ownership perform better in developed countries than there institutional ownership while in developing countries their results are mixed. Zouari, $\mathrm{S}(2014)$.

\subsection{Financial Performance;}

The studies that conducted to explore the financial performance of Islamic banks are partial literature as compared to conventional banks literature on this subject. Financial ratios are used to determine the banking efficiency and governance aspects are unobserved in the literature. In premature studies of Islamic banking sector, Sarkar, (1999) conducted a study to explore the operational efficiency and performance of Islamic banks. $\mathrm{He}$ found that Islamic banks carry on their operations within framework of conventional banking in Bangladesh. Western scholar (Volker Niehanus; 2006) argued that the Islamic banking worldwide improve way of thinking and value structure which attributes slight value to individual responsibility and performance.

In 2001, Bashir conducted a study to examine the fundamentals determinants of Islamic banks performance in the Middle East. He concluded that the Islamic banks profits are frequently generated from non-interest earning assets, short term customer funding and overheads by using regression equation method. Soon after in 2003, Bashir also focuses on four elements of Islamic banks performance (return on equity, return on asset, profit margin and the net non-interest margin) among 1993 to 1998 diagonally Eight Middle Eastern countries. The result depicts that loan to asset and high capital to asset direct Islamic banks to have elevated profitability. He also found that foreign owned banks are most profitable.

Ownership mix and performance:

The review of previous studies explains distinctly ownership mix and firm financial performance, in ownership mix included ownership of different investors like government family, individual, institution and foreign companies etc. Empirical findings show both positive and negative impact of ownership mix on financial performance of banks. Studies that have tried to explain the performances of Islamic banks are limited as Compared to the rich literature on this concern for conventional banks (Zouari \& Taktak, 2012) at the present Islamic bank exist all over the world while it was initially developed to accomplish the need of Muslim.

Abraham, (2013) conducted a study on foreign ownership and financial performance of banks in Saudi Arabia and concluded that capital structure loan portfolios and regulatory tier 1 capital are extra violent due to foreign ownership and these are incapable to leads the better financial performance. In Pakistan a study conducted by Shagufta and ayub, (2014) on ownership mix and financial performance of firm. The researchers concluded that local and foreign investor, financial and government institutions are significantly related to the banks financial performance. Whereas major shareholders associated firms and local investor are negatively related to the financial performance of banks. A study conducted by Musa \& Abdu (2017) in Nigeria on ownership structure and corporate performance of banks and concluded that ownership structure is an important element for better performance of firm. Zouari \& Taktak (2012) found the relationship between ownership structure and financial performance of firm and concluded that the family and state ownership directly related to the firm performance and also suggested that foreign and institutional shareholder are not bitterly perform.

In India Rajput \& Bharti (2015) conducted a study on impact of shareholder types, corporate governance and firm performance. The researchers concluded that foreign institutional and foreign investors directly and positively related to the ROE whereas government and retailor shareholder indirectly related to the return on equity (ROE). In (2007) Rami \& Gray conducted a study on ownership structure and concluded that government share expressively and inversely related to the firm financial performance ROE. Researcher also discussed defaulted and non-defaulted firms and concluded that government ownership expressively and inversely related to the performance of default. Results of this study further recommend that reducing government ownership can improve the performance of firm but will also cause some firms to go bankrupt, at least in the short term.

\section{Ownership concentration and performance:}

Ownership concentration shows the direct equity held by the shareholders. Empirical findings shows both positive and negative impact of ownership Concentration on financial performance of banks and also suggested 
that there is a complex and empirical relationship between ownership concentration and firm financial performance due to conflicting and ambiguous results(Demsetz, 1983; Demsetz \& Lehn 1985; Shleifer \& Vishny, 1986; Wu \& Cui 2002). In Pakistan a study conducted by Shagufta \& ayub, (2014) on ownership concentration and financial performance of firm. The researchers concluded that major shareholders and local investors indirectly related to the financial performance of banks. Zouari \& Taktak (2012) found the relationship between ownership structure and financial performance of firm and concluded that there is no direct relation between ownership concentration and firm performance.

Peterson \& olayinka, (2017) founded the relationship between ownership concentration and banks profitability. The researchers focus on high moderate and disperse ownership structure and concluded that high ownership concentration revels higher interest margin, earning power and higher return on assets (ROA). Whereas disperse ownership concentration revels higher return on equity (ROE) but lower return on assets (ROA). Results of this study also suggested that moderate ownership concentration effectively improve the return on assets (ROA) and return on equity (ROE).In (2007) Rami and Gray conducted a study on ownership structure and concluded that defaulted firms have high ownership concentration as compared to non-defaulted firms whereas C5 (Largest five shareholder) expressively and inversely effected the performance of default.

In Germany (2000) Groton \& schmid conducted a study on ownership concentration and concluded that ownership concentration directly related to the performance market to book ratio and return on assets (ROA). The results of Claessens et al. (2002) also support this study on performance of Asian firms. Whereas Zeitun \& Tian (2007) concluded that ownership concentration directly and significantly related to the return on assets (ROA) and return on equity (ROE). In United Kingdom (1991) leech and Leahy conducted a study on ownership concentration and firm financial performance and concluded indirect relationship between ownership concentration and firm performance.

\section{Framework}

In this study researchers found the relationship among different variables ownership concentration $(\mathrm{C} 1, \mathrm{C} 3, \mathrm{C} 5)$ and ownership mix (INST, GOV, FML, FORG) variables effect the financial performance (ROA ,ROE) of Islamic banks. Financial performance of Islamic banks use as dependent and ownership structure (concentration and mix) independent variable, while bank characteristics (CAR, LEV, SIZE) and macroeconomic factors (GDP, INF) control variables, The graphical model of our study is followings;

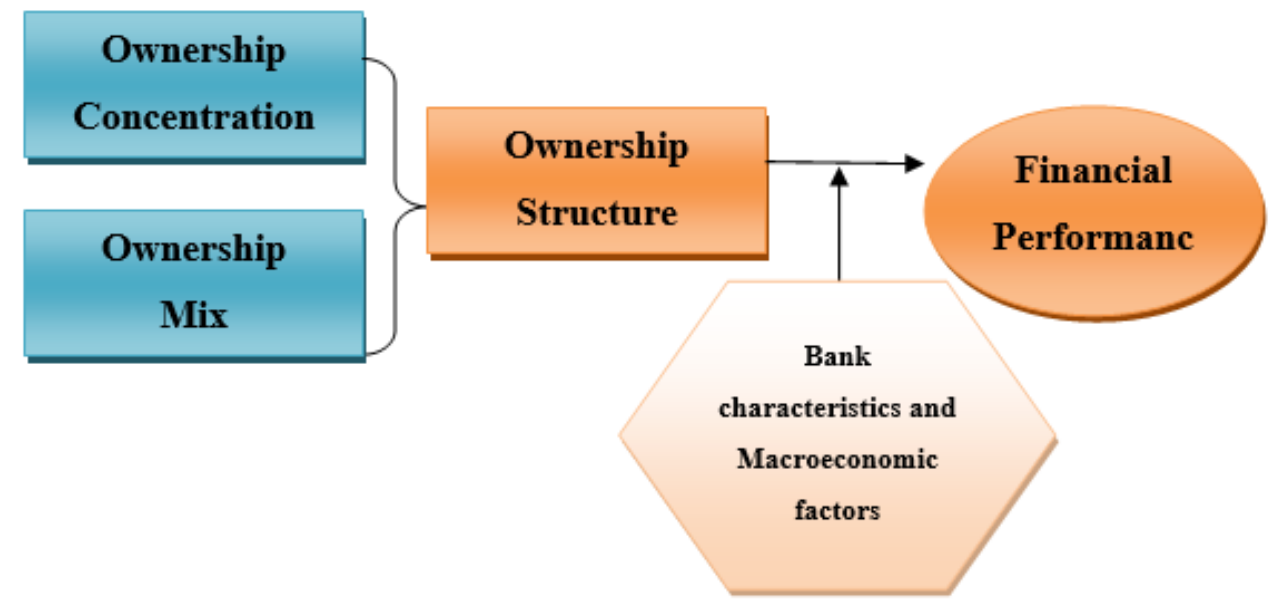

\section{Figure 1 Framework \\ Source; Develop By Authors}

\section{Data and Methodology}

The basic aim of this study is to examine the determinants of ownership structure in Islamic banking. The research was conducted in Pakistan for this purpose $\mathrm{C} 1, \mathrm{C} 3$ and $\mathrm{C} 5$ variables use for ownership concentration, family, individual, institutional and government use for ownership mix as an independent variable and used bank characteristics and micro economic factor as a control variables and their impact on financial performance check through Return on assets (ROA) and return on equity (ROE).Multiple techniques such as descriptive, regression and correlation analysis are used to check the ownership structure and financial performance of Islamic banking in Pakistan. We used secondary Data collected from published annual reports of Islamic banks and World Bank database and apply E-views software to check ownership structure and their impact on performance of Islamic banking. 


\subsection{Data collection}

Secondary data collected from published annual reports of Islamic banks for the period of 2008 to 2017 and the data of microeconomics factors collected from World Bank database. The nature of this study is quantitative.

\subsection{Variables}

C1, C3 and C5 for ownership concentration in ownership mix institutional, government, family and foreign shareholders included and in control variables used microeconomic factors (inflation, and GDP) and bank characteristics (CAR, SIZE, LEV) and their impact on financial performance of Islamic banks check through Return on assets (ROA) and return on equity (ROE)Sarra \& Neila (2014).

1-1 Description of Variables

\begin{tabular}{|c|c|c|c|}
\hline Variables & Determinants & Details & Notations \\
\hline \multicolumn{4}{|l|}{ Dependent } \\
\hline \multirow[t]{2}{*}{ Financial Performance } & Return on Assets & Net Income /Total assets & ROA \\
\hline & Return on Equity & Net Income / Total Equity & ROE \\
\hline \multicolumn{4}{|l|}{ Independent } \\
\hline \multirow[t]{7}{*}{$\begin{array}{c}\text { Ownership Structure } \\
\text { (Concentration and Mix) }\end{array}$} & $\mathrm{C} 1$ & $\begin{array}{l}\text { The percentage of shares held by the } \\
\text { largest shareholder. }\end{array}$ & $\mathrm{C} 1$ \\
\hline & $\mathrm{C} 3$ & $\begin{array}{l}\text { The percentage of shares held by first } \\
\text { three largest shareholders. }\end{array}$ & $\mathrm{C} 3$ \\
\hline & $\mathrm{C} 5$ & $\begin{array}{l}\text { The percentage of shares held by first five } \\
\text { largest shareholders }\end{array}$ & $\mathrm{C} 5$ \\
\hline & $\begin{array}{l}\text { Institutional } \\
\text { investor }\end{array}$ & $\begin{array}{l}\text { The percentage of shares held by } \\
\text { Institutional Shareholders }\end{array}$ & INST \\
\hline & Government owner & $\begin{array}{l}\text { The percentage of shares held by State or } \\
\text { Government Shareholders }\end{array}$ & GOV \\
\hline & Family Owner & $\begin{array}{l}\text { The percentage of shares held by Family } \\
\text { shareholders }\end{array}$ & FAM \\
\hline & $\begin{array}{l}\text { Foreign } \\
\text { Shareholders }\end{array}$ & $\begin{array}{l}\text { The percentage of shares held by Foreign } \\
\text { Shareholders }\end{array}$ & FORG \\
\hline \multicolumn{4}{|l|}{ Control } \\
\hline \multirow[t]{5}{*}{$\begin{array}{l}\text { Banks Characteristics and } \\
\text { Economic factors }\end{array}$} & $\begin{array}{l}\text { Capital adequacy } \\
\text { ratio }\end{array}$ & Total Equity / Total assets & CAR \\
\hline & Bank size & The logarithm of total assets of the bank & SIZE \\
\hline & Leverage ratio & Total Debt / Total assets & LEV \\
\hline & $\begin{array}{l}\text { Gross Domestic } \\
\text { Product }\end{array}$ & Gross Domestic Product & GDP \\
\hline & Inflation & Inflation rate & INFL \\
\hline
\end{tabular}

\section{Dependent variables:}

- Return on assets (ROA): Return on assets is defined as Net Income to total assets it's refer to the firm financial position like how many assets a firm have and ability to generate profit from assets.(Masood, and Ashraf. 2012)(Ashraf et 2017).(Hassoune 2002). Ben Naceur (2003)

- Return on equity (ROE): Return on equity calculated through Net income / total equity its show the use of funding to generate profit. Return on equity used to measure the financial performance.(Masood, and Ashraf. 2012)(Ashraf et 2017).(Bashir and Hassan 2004) return on equity shows the efficiency of management towards shareholders' investment.(Hassoune 2002).

\section{Independent variables:}

Ownership concentration (OC): $\mathrm{C} 1, \mathrm{C} 2$, and C5: C1 shows the first largest shareholders of the bank Whereas in C3 use percentage of first three largest shareholders and C5 shows the percentage of first five largest shareholders of banks (Sarra and Neila 2014).(Sarra and Neila 2012).

Ownership mix: In ownership mix family government institutions and foreign shareholders included.(Thomsen and Pedersen, 2000)

- Family ownership (FAM): Family ownership use as an independent variable in current study and data of this variable is collected from published annual reports of Islamic banks Pakistan. Family ownership shows the family owns companies and included shares of director's spouse children and other family members. Family ownership positively related to the firm performance and also decrease agency cost of firm, Amoako-Adu (1999)(Villalonga and Amit 2006; Anderson and Reeb 2003).(Sarra and Neila 2012).

- Government ownership (GOV): Government ownership use as an independent variable in current 
study and data of government ownership is collected from published annual reports of Islamic banks Pakistan .In state we use two views first is development and second is political view both are most important for economic and financial development because government ownership provide employment opportunities to people. La Porta et al. (2002)(Sarra and Neila 2012).

- Institutions ownership (INST): Institutional ownership use as an independent variable in current study the data of institutional ownership is taken from published annual reports of Islamic banks. Institutional shareholders provide appropriate encouragement to the management and shareholders of company Shleifer and Vishny (1986) institutional shareholders same as other company's shareholder they have same rights and duties like other large shareholders, Agrawal and Knoeber (1996) concluded insignificant relationship whereas Smith (1996)conclude direct relationship between institutional ownership and firm performance.(Sarra and Neila 2012).

- Foreign ownership (FORG): Foreign ownership use as an independent variable in current study. The data of foreign ownership is collected from published annual reports of Islamic banks Pakistan .A firm with foreign ownership perform better as compared to domestic owned shares whereas foreign ownership enhance firm performance and also decrease the agency cost of the firm Sarkar and Sarkar (2000) and Bonin et al. (2004). Foreign ownership also increase the efficiency of firm and improve management talent in domestic level and also decline the operative cost Suffian (2006) and Claessens et al. (2001).

Control Variables;

In this study Bank characteristics and Microeconomic factors use as control variables.

Bank characteristics:

- Capital adequacy (CAR): Capital adequacy use as a control variable in current study is taken as total equity to total assets. The data of capital adequacy is collected from published annual reports of Islamic bank Pakistan.(Sarra and Neila 2014).

- Bank Size (BS): Bank size use as a control variable in current study bank size is taken log of total assets of bank. The data of bank size is collected from the annual reports of firm. Bank size provides information about financial position of Bank. (Cornett M, et al, 2005; Kutan et al., 2012; Nizdak\& Maryam, 2012; Pathan\& Faff, 2013).(Shama Noreen, 2017)

- Leverage ( $\boldsymbol{L E V}$ ): Leverage use as a control variable in current study is taken ratio of total debt to total assets of bank. The data of leverage is taken from the balance sheet of published annual report of Islamic bank Pakistan.(Sarra and Neila 2014).

\section{Microeconomic factors:}

- Inflation (INF): Inflation use as a control variable in current study and their data collected from the World Bank database.(Sarra and Neila 2014).

- Gross domestic product (GDP): Gross domestic product use as a control variable in current study and their data collected from the World Bank database.(Sarra and Neila 2014).

\subsection{Econometric model:}

In this study researcher found the relationship among different variables ownership concentration and ownership mix with financial performance of Islamic banks. The financial performance of Islamic banks use as dependent variable, in balance panel data, the model consists I cross-section units, denoted $\mathrm{i}=1$, observe every one of $\mathrm{T}$ time period, $\mathrm{t}=1$. In data position, the total observation is $\mathrm{I} \times \mathrm{T}$. The essential framework for the balance panel data we define in the following regression model:

$$
Y_{I T}=\alpha+\beta x_{I T}+\varepsilon_{I T} \ldots \ldots \ldots \ldots(1)
$$

In above model the dependent variable (financial performance) denoted by $Y_{I T}, \alpha$ represents constant coefficient, independent variables (Ownership concentration and mix) denoted by $\beta x_{I T}$ and $\varepsilon_{I T}$ use for error term.In previous studies regression model also used for examination of sample data (Ashraf et al. 2017). For this study regression models are given below;

$$
\begin{aligned}
& R O A=\alpha+\beta_{1} C 1_{I T}+\beta_{2} C 3_{l T}+\beta_{3} C 5_{I T}+\beta_{4} I N S T_{I T}+\beta_{5} G O V_{I T}+\beta_{6} F A M_{I T}+\beta_{7} F O R G_{I T}+\varepsilon_{I T} \\
& R O E=\alpha+\beta_{1} C 1_{I T}+\beta_{2} C 3_{I T}+\beta_{3} C 5_{I T}+\beta_{4} I_{I N T}+\beta_{5} G O V_{I T}+\beta_{6} F A M_{I T}+\beta_{7} F O R G_{I T}+\varepsilon_{I T}
\end{aligned}
$$

\section{Result and Discussion:}

In this section descriptive statistics, correlation and regression analysis tables and detail discussion are given. 


\subsection{Descriptive Statistics}

Table 2-1Ownership Measures (Concentration and Mix)

\begin{tabular}{|l|c|c|c|c|}
\hline Variables & Mean & Minimum & Maximum & Std.Deviation \\
\hline C1 & 23.81 & 8.84 & 49.12 & 13.72 \\
\hline C3 & 18.18 & 9.91 & 29.47 & 7.07 \\
\hline C5 & 12.93 & 7.78 & 18.64 & 3.70 \\
\hline INST & 55.59 & 0.01 & 90.38 & 27.89 \\
\hline GOV & 5.57 & 0.76 & 15.50 & 2.37 \\
\hline FAM & $9 . .77$ & 0.02 & 25.69 & 3.13 \\
\hline FORG & 2.92 & 1.97 & 19.66 & 01 \\
\hline
\end{tabular}

In table-1 displays descriptive statistics of ownership structure (Concentration and Mix). Ownership concentration measures C1shows largest shareholder, C3 shows first three largest shareholders and C5 shows first five largest shareholders. The largest shareholder (C1) owns the value of mean, minimum and maximum, 23.81\%, 8.84 and 49.12\% respectively. C3 (the first three largest shareholders) and C5 (first five largest shareholders) owns the value of mean, minimum and maximum below as compare to $\mathrm{C} 1$. The ownership concentration results depicts that Islamic banks of Pakistan have largest control in hands of single shareholder. Same results found by Sarra \& Neila (2014) and Becht \&S Roell, (1999). On the other hand institutional, government, family and foreign shareholders used to measure ownership mix, with the help of this we tried to found the nature ownership in Islamic banks of Pakistan. The results depicts that the ownership part is mostly concentrated in hands of institutional shareholders and infrequently in hands government or family investors.

Table 2-2 Dependent and Control Variables

\begin{tabular}{|l|c|c|c|c|}
\hline Variables & Mean & Minimum & Maximum & Std.Deviation \\
\hline ROA & 0.01 & -0.02 & 0.02 & 0.01 \\
\hline ROE & 0.99 & -0.17 & 0.31 & 0.12 \\
\hline CAR & 8.15 & 7.21 & 8.99 & 0.47 \\
\hline SIZE & 0.08 & 0.04 & 0.27 & 0.04 \\
\hline LEV & 0.91 & 0.72 & 1.07 & 0.05 \\
\hline GDP & 0.72 & 0.01 & 5.06 & 1.56 \\
\hline INFL & 1.83 & 0.01 & 20.28 & 4.49 \\
\hline
\end{tabular}

Table-2 report descriptive statistics of dependent (ROA and ROE) and control variables (CAR, SIZE, LEV, GDP and INFL). The results depict that low variation in performance measure ROA and ROE. The value of standard deviation of ROA and ROE is $1 \%$ and $12 \%$ respectively. The lower values of standard deviation indicate the lower volatility of earnings and lower risk of Islamic banks in Pakistan. CAR (Capital adequacy ratio) shows that Islamic banks are well capitalized with equity and leverage ratio (LEV) also in comfortable range.

\subsection{Correlations Results}

Table 2-3 Correlations Results

\begin{tabular}{|l|l|l|l|l|l|l|l|l|l|l|l|l|l|l|}
\hline & ROA & ROE & C1 & C3 & C5 & INST & GOV & FAM & FORG & CAR & SIZE & LEV & GDP & INFL \\
\hline ROA & 1 & & & & & & & & & & & & & \\
\hline ROE & 0.80 & 1 & & & & & & & & & & & & \\
\hline C1 & 0.34 & 0.60 & 1 & & & & & & & & & & & \\
\hline C3 & 0.24 & 0.46 & 0.95 & 1 & & & & & & & & & & \\
\hline C5 & 0.17 & 0.36 & 0.91 & 0.95 & 1 & & & & & & & & & \\
\hline INST & 0.15 & 0.27 & 0.74 & 0.76 & 0.76 & 1 & & & & & & & & \\
\hline GOV & 0.04 & 0.06 & -0.1 & -0.2 & -0.2 & -0.08 & 1 & & & & & & & \\
\hline FAM & -0.33 & -0.53 & -0.5 & -0.4 & -0.3 & -0.42 & 0.13 & 1 & & & & & & \\
\hline FORG & -0.15 & -0.27 & -0.3 & -0.3 & -0.2 & -0.36 & -0.21 & 0.46 & 1 & & & & & \\
\hline CAR & 0.53 & 0.68 & 0.15 & -0.2 & -0.1 & -0.17 & 0.10 & -0.28 & 0.03 & 1 & & & & \\
\hline SIZE & -0.35 & -0.50 & -0.2 & -0.1 & -0.2 & 0.03 & -0.1 & 0.24 & 0.07 & 0.70 & 1 & & & \\
\hline LEV & 0.37 & 0.49 & 0.14 & -0.1 & 0.03 & 0.01 & 0.07 & -0.24 & 0.07 & 0.70 & -0.90 & 1 & & \\
\hline GDP & 0.32 & 0.67 & 0.86 & 0.74 & 0.65 & 0.56 & 0.03 & -0.50 & -0.35 & 0.39 & -0.28 & 0.22 & 1 & \\
\hline INFL & 0.29 & 0.47 & 0.74 & 0.65 & 0.58 & 0.49 & 0.02 & -0.43 & -0.31 & 0.10 & -0.18 & 0.13 & 0.58 & 1 \\
\hline
\end{tabular}

In table-3 represents the one to one correlation results in dependent, independent and control variables. According to correlation matrix the measures of ownership concentration $(\mathrm{C} 1$ : The percentage of shares held by the largest shareholder, C3:The percentage of the first three largest shareholders, C5:The percentage of the first five largest shareholders) shows positive relationship with financial performance (ROA: return on assets and 
ROE: return on equity). On the other hand, INST (institutional shareholders) and GOV (state ownership) also shows positive impact on financial performance (ROA and ROE), while FAM (family shareholders) and FORG (foreign investors) have negative relationship with ROA and ROE.The measures of ownership concentration (C1, C3 and C5) and mix (INST, GOV, FAM and FORG) have correlated with each other due to investment relationship. All other control variables not highly correlated with each other.

\subsection{Regression Results}

In table-4 put Regression results and return on asset use as dependent variable.

Table 2-4 Return on Assets (ROA)

\begin{tabular}{|c|c|c|c|}
\hline Variables & Coefficient & T.Statistics & Prob. \\
\hline $\mathbf{C}$ & -0.0036 & -0.7513 & 0.4568 \\
\hline ROE & 0.0764 & 8.0063 & 0.0000 \\
\hline C1 & -0.0004 & -1.8407 & 0.0729 \\
\hline C3 & 0.0002 & 0.4454 & 0.6584 \\
\hline $\mathrm{C5}$ & 0.0001 & 0.2500 & 0.8038 \\
\hline INST & 6.0433 & 1.3684 & 0.1786 \\
\hline GOV & -0.0001 & -0.5289 & 0.5997 \\
\hline FAM & 0.0001 & 1.2563 & 0.2161 \\
\hline FORG & -0.4905 & -0.0577 & 0.9543 \\
\hline R-Squared & 0.7120 & & \\
\hline Prob(F.statistaic) & 0.0000 & & \\
\hline
\end{tabular}

The results demonstrates that value of R-square 0.7120 which tells about $71.20 \%$ of variability of profitability ROA (return on assets) is explained by ownership structure (Concentration and Mix). The value of Prob. 0.0000 describe about the significance of model. The largest shareholder $(\mathrm{C} 1)$ has significantly negative impact on financial performance indicator ROA (return on assets), while C3 (The percentage of the first three largest shareholders) and C5 (The percentage of the first five largest shareholders) have positively but insignificant related. On the other hand Government (GOV) and Foreign (FORG) shareholders negatively and insignificantly related to the ROA (return on assets).

Table 2-5 Return on Equity (ROE)

\begin{tabular}{|l|c|c|c|}
\hline Variables & Coefficient & T.Statistics & Prob. \\
\hline ROA & 0.1095 & 2.3250 & 0.0251 \\
\hline C1 & 7.9798 & 8.0063 & 0.0000 \\
\hline C3 & 0.0091 & 4.6090 & 0.0000 \\
\hline C5 & -0.0050 & -0.9574 & 0.3439 \\
\hline INST & -0.0086 & -1.0849 & 0.2843 \\
\hline GOV & -0.0009 & -2.1655 & 0.0362 \\
\cline { 1 - 2 } FAM & 0.0033 & 1.0162 & 0.3155 \\
\cline { 1 - 2 } FORG & -0.0030 & -2.6124 & 0.0125 \\
\hline R-Squared & 0.0012 & 0.4881 & 0.6280 \\
\cline { 1 - 2 } Prob(F.statistaic) & 0.8607 & & \\
\hline
\end{tabular}

Table-5 reported that the regression analysis of performance measure return on equity (ROE). The results depict that ownership concentration indicators C3 (the percentage of the first three largest shareholders) and C5(the percentage of the first five largest shareholders) have insignificantly negative related to return on equity (ROE), while in ownership mix INST (institutional shareholders) and FAM (family shareholders) also have significantly negative impact on return on equity. On the other hand GOV (State ownership) and FORG (foreign) shareholders have insignificant positive impact on return on equity (ROE), whereas ownership concentration indicator $\mathrm{C} 1$ (The percentage of shares held by the largest shareholder) shows significant positive relationship with financial performance (ROE). The value of R-square 0.8607 which tells about $86.07 \%$ variability of return on equity (ROE) due to ownership structure (Concentration and Mix), while the value of Prob. 0.0000 describe about the significance of model.

\section{Summary of Findings}

Results for the two models estimating performance with three ownership concentration measures $(\mathrm{C} 1$ : The percentage of shares held by the largest shareholder, C3: The percentage of the first three largest shareholders, C5: The percentage of the first five largest shareholders) and four owner's identity specifications (institutional, foreign, government and family ownership) are shown inTables2-4and2-5 respectively, for ROA and ROE.

The measures of ownership concentration (C1, C3 and C5) demonstrate presence of some impact on Islamic 
bank performance (ROA and ROE) in the entire regression models. These results are inconsistent with the objectivity thesis sophisticated by Demsetz, (1983) and reported by further studies of conventional banks (Sarra \& Neila, 2014; Demsetz \& Lehn, 1985; Holderness \& Sheehan, 1988). In early studies, for Islamic banks ownership concentration is not considered as an important variable, and considered that the banks value maximization is only depends on external environment and banks operational characteristics. But the results indicate that Islamic banks performance also influence with ownership concentration.

According to regression results of ROA, INST (institutional shareholders) and FAM (family shareholders) have positive impact on bank performance in ROA model. This result is consistent with finding of Abbas et al. (2009), while we find a negative relationship between GOV (State ownership) and bank performance ROA, in contradiction with the findings of (Sarra \& Neila, 2014; Abbas et al. 2009).In consequence, performance of GOV-owned banks decreases when the government is a large shareholder, signifying that GOV (State ownership) is less good at your job than private ownership. FORG (foreign) shareholders also have negative impact on ROA; this result is consistent with (Sarra \& Neila, 2014; Sufian and Habibullah, 2010).

According to regression results of ROA, INST (institutional shareholders) has significantly negative impact on ROE, this finding are inconsistent with result of Sarra \& Neila, (2014), while INST (institutional shareholders) also has significantly negative impact on ROE, this results is consistent with Sarra \& Neila, (2014). GOV (State ownership) and FORG (foreign) shareholders have positive impact on ROE but insignificant. The contradiction between our and the results of past studies might be due to the difference multiple countries data and the time period of data. But, our research is only on the Islamic banking sector of Pakistan and we use the data of recent years.

\section{Conclusion}

The impact of ownership concentration on financial performance has an innermost question in field of finance research. In this project, we observe the relationship between ownership concentration and Islamic bank performance in Pakistan. Family, foreign, institutional and government investors are the key shareholders that portray the capital of Islamic banks in Pakistan. We use five Islamic banks of Pakistan as sample of study, for the purpose of examining the key owners of these Islamic banks and the effect of the different types of ownership on banks performance.

The findings of this study shows in different forms. Firstly, we found that ownership concentrated (equity ownership) is a frequent feature in Islamic banks of Pakistan. The largest investor (shareholder) owns almost $49.12 \%$ of Islamic banks capital in Pakistan, while 60 to $70 \%$ capital (equity) is owned by top fifth shareholders (investors). Thus we concluded that the ownership of Islamic banks in Pakistan is highly concentrated, therefore we are able to provide some extra substantiation that a small portion of Islamic banks have a single ownership structure. Secondly, the findings suggest that in sample of our study the majority of the Islamic banks of Pakistan are institutionally (INST) and family (FAM) owned.

On the other hand, ROA and ROE use as indicators of financial performance, the regression results also exposed that ownership concentration are related with performance as investigate in this project. The results of our study suggest that family and institutional ownership positively affect bank's performance in Pakistan. They indicate also that banks with state and foreign shareholders are not performing than those who are institutionally and family owned. Due to this, it also considered that the bank value maximization is not only effected with external environment and banks operational characteristics, but also from ownership concentration.

The findings of the study have important implications because they add to the literature on exploring the importance of the ownership structure (concentration and mix) relationship with the performance between the Islamic financial institutions. Findings provided useful information to bank managers, investors and policy makers. Financial performance can be improved by identifying practices associated with ownership structure So, it will have policy implications for Islamic banks as to how to improve their performance in Pakistan. Finally, different types of bank ownership have different concerns about implementing corporate governance practices among Islamic banks. For further research, it is highly recommended to cover more Islamic banks, and it is interesting to include the percentage of the largest capital held referring to owner category instead of dummy variables.

\section{References}

1. Abdallah, A \& Ismail, K.(2017) “Corporate governance practices, ownership structure, and corporate performance in the GCC countries". Journal of International Financial Markets Institutions and Money, 46, 98-115.

2. Abbas, S.Z., Rahman, R.A. and Mahenthiran, S. (2009), "Ultimate ownership structure and performanceofIslamicinstitutionsinMalaysia”,FMA International First Asian Conference

3. Ashraf, M., Ameen, A \& Shahzadi, k (2017) “The Impact of Capital Structure on Firm's Profitability: A Case of Cement Industry of Pakistan”. International Journal of Business and Social Science, Vol. 8, No. 
4

4. Athanasoglou, P, Brissimis, S \& Delis, M.D. (2005), "Bank-specific, industry specific and macroeconomic determinants of bank profitability", MPRA Paper No. 153

5. Alam, I \& Deb, S.K. (2010), "Human resource accounting disclosure (HRAD) in Bangladesh: multifactor regression analysis-a decisive tool of quality assessment", The Cost and Management, Vol. 38, No. 3, pp. 9-13.

6. Anderson, R.C, Reeb, D.M. (2003) "Founding-family ownership and firm performance: evidence from the S\&P 500. "Journal of Finance. 58. 1301-1328.

7. Banghøj, J \& Plenborg, T. (2008), "Value Relevance of Voluntary Disclosure in the Annual Report," Accounting and Finance, Vol. 48, No. 2, pp. 159-180.

8. Bian, W \& Deng, C.(2017).Ownership dispersion and bank performance: Evidence from China. Finance Research Letters (https://doi.org/ 10.1016/j.frl.2016.12.030).

9. Bashir, Abdel-Hameed (2001) "Assessing the Performance of Islamic Banks: Some Evidence from the Middle East." American Economic Association Annual Meeting, New Orleans, Louisiana

10. Bashir, Abdel-Hameed (2003) "Determinants of Profitability in Islamic banks: Some Evidence from the Middle East." Islamic Economic Studies 11, No. 131:-57.

11. Berle, A \& G. Means (1932), The Modern Corporation and Private Property, Harcourt, Brace, \& World, New York.

12. Barako, D. G., Hancock, P. \& Izan, H. Y. (2006), "Factors influencing voluntary corporate disclosure by Kenyan companies", Corporate Governance: An International Review, Vol. 14 No. 2, pp. 107-125.

13. Cooke, T.E. (1989). "Voluntary Corporate Disclosure by Swedish Companies" Journal of International Financial Management and Accounting, Vol. 1, No. 2, pp. 171-195

14. Chau, G.K. \& Gray, S.J. (2002), "Ownership structure and corporate voluntary disclosure in Hong Kong and Singapore”, The International Journal of Accounting, Vol. 37, No. 2, pp. 247-65

15. Demsetz, H. (1983), "The structure of ownership and the theory of the firm", Journal of Law and Economic, Vo1 26 No. 2, pp. 357-390

16. Demsetz, H. and Lehn, K. (1985), "The Structure of corporate ownership: causes and consequences", Journal of Political Economy, Vol. 93 No. 6, pp. 1155-1177.

17. Demsetz, H \& Villalonga, B (2001) "Ownership structure and corporate performance" Journal of Corporate Finance 7, 209-233

18. Eng, L. L. \& Mak, Y. T. (2003), "Corporate governance and voluntary disclosure”, Journal of Accounting \& Public Policy, Vol. 22, No. 4, pp. 325-345

19. Fama, E. \& M. C. Jensen (1983), "Separation of Ownership and Control", Journal of Law and Economics, Vol. 26, pp. 301-25.

20. Haniffa, R.M. \& Cooke, T.E. (2002), "Culture, Corporate Governance and Disclosure in Malaysian Corporations", Abacus, Vol. 38, No. 3, pp. 317-349.

21. Huafang, X. \& Jianguo, Y. (2007), “Ownership structure, board composition and corporate voluntary disclosure: Evidence from listed companies in China", Managerial Auditing Journal, Vol. 22, No. 6, pp. $604-619$

22. Hossain, M, Tan, L \& Adams, M. (1994), "Voluntary disclosure in an emerging capital market: some empirical evidence from companies listed on the Kuala Lumpur Stock Exchange", The International Journal of Accounting, Vol. 29, pp. 334-51

23. Holderness, C.G. and Sheehan, D.P. (1988), "The role of majority shareholders in publicly held corporations: an exploratory analysis", Journal of Financial Economics, Vol. 20 Nos. 1/2, pp.317-346.

24. Iannotta, G, Nocera,G \& Sironi,A (2007)."Ownership structure, risk and performance in the European banking industry"Journal of Banking Finance, 31(7), 2127-2149

25. Jensen, M. \& W. Meckling (1976), "Theory of the firm: Managerial Behavior, Agency costs and Ownership Structure", Journal of Financial Economics, Vol. 3, pp. 305-60.

26. Khakan \& Rabia, (2016) "Growth of Islamic Banking in Pakistan"Arabian Journal of Business and Management Review 6;4

27. Lakhal, F. (2007), "Ownership Structure and Voluntary Disclosures: The Case of French listed firms," Corporate Ownership and Control, Vol. 5, No.1, pp. 131-138.

28. Leech, D \& Leahy, J. (1991), “Ownership structure, control type classifications and the performance of large British companies”, The Economic Journal, Vol. 101 No. 409, pp.1418-1437

29. Lehmann, E \& Weigand, J (2000) Does the governed corporation perform better? Governance structures and corporate performance in Germany, European Finance Review, 4(2), 157-195

30. Lepore, L, Paolone, F, Pisano, S \& Alvino, F (2017) Across-country comparison of the relationship between ownership concentration and firm performance: Does judicial system efficiency matter? Corporate Governance: The International Journal of Business in Society, 17(2), 321-340. 
31. La Porta, R, Lopez-de-Silanes, F \& Shleifer, A., (1999). Corporate ownership around the world Journal of Finance 54,471$\} 518$

32. Ntim, C \& Soobaroyen, T. (2013) "Corporate governance and performance in socially responsible corporations: New empirical insights from a Neo-Institutional framework". Corporate Governance: $A n$ International Review, Vol. 21, No. 5, pp. 468494.

33. Phung, D \& Mishra, V (2016) Ownership structure and firm performance: Evidence from Vietnamese listed firms. Australian Economic Papers, 55(1), 63-98.

34. Pervan, M.,Pervan,I.,\& Todoric,M.(2012). Firm ownership and performance: Evidence for Croatian listed firms. World Academy of Science, Engineering and Technology, 61, 964-970.

35. Patelli, L \& Prencipe, A (2007), "The relationship between voluntary disclosure and independent directors in the presence of a dominant shareholder", European Accounting Review, Vol. 16, No. 1, pp. $5-33$

36. Shleifer, A \&Vishny (1986), "Large shareholders and Corporate Control", Journal of Political Economy, Vol. 94, pp. 461-88

37. Smith, A.J. 16 (1996):"“Corporate ownership structure and performance, managerial ownership and the size effect. Journal of Portfolio Management. 33-39.

38. Sarker, Md. \& Abdul Awwal (1999): "Islamic banking in Bangladesh: performance, problems and prospects." International Journal of Islamic Financial Services 1/ No.3 15-36.

39. Sarkar, J. and Sarkar, S. (2000)"Large shareholder activism in corporate governance in developing countries: evidence from India". International Review of Finance. 161-194.

40. Sufian, F. \& Habibullah, M.S. (2010) "Does foreign banks entry fosters bank efficiency empirical evidence from Malaysia", Engineering Economics, Vol. 21 No. 5, pp. 464-474

41. Sufian, F. (2006) "Size and returns to scale of the Islamic banking industry in Malaysia: Foreign

42. versus domestic banks." IIUM Journal of Economics and Management. 14. 2

43. Tsamenyi, M, Enninful, E \& Onumah, J. (2007), "Disclosure and corporate governance in developing countries: evidence from Ghana", Managerial Auditing Journal, Vol. 22, No. 3, pp. 319-334.

44. Thomsen, S. and Pedersen, T. (2000) "Ownership structure and economic performance in the largest European companies." Strategic Management Journal. 689-705.

45. Villalonga, B. and Amit, R.H. (2006): "How Do Family Ownership, Control and Management Affect Firm Value?" Journal of Financial Economics.80, 385-417.

46. Welch, E (2003).The relation between ownership structure and performance in listed Australian companies. Australian Journal of Management, 28(3), 287-30 